\title{
The Adaptation of Consonants from English Loanwords into Bemba
}

\author{
Kangwa Njenje Kennedy \\ Department of Linguistics, Kwame Nkrumah University, Kabwe - Zambia \\ *Corresponding Author: Kangwa Njenje Kennedy, Department of Linguistics, Kwame Nkrumah \\ University, Kabwe - Zambia
}

Abstract: This study investigates how Bemba, a Bantu language adapts loanwords (consonants in particular) from English (Indo - European) to suit its pre-existing phonology. This adaption is expected because these two languages belong to two different language families. Because of this difference, Bemba employs ways to rephonologise new words borrowed into its vocabulary to fit, and to conform to native structure demands. English has 25 consonants while Bemba on the contrary, has 15. Such distinctions in phonological inventories cause for loanword adaptation. Although Bemba employs repair strategies such as vowel epenthesis and consonant deletions among others to adapt loanwords, this study will limit itself to consonant preservation and consonant substitutions only.

Keywords: borrowing, devoicing, native segment inventory, laterlisation, fricatisation, source language (SL), receiving language $(R L)$

\section{INTRODUCTION}

Borrowing is a process through which languages acquire new lexis from other languages (Swann, Deumert, Lillis, \& Mesthrie, 2004). When words are adopted from one language to another certain sounds may be substituted by others. There are various factors which lead to the substitution of sound segments in adapted words. In this study, substitution occurs because of lack of the equivalent sound segments in the recipient language. The sounds and forms which are incompatible with the sound segments of the receiving language are replaced by native ones. This type of substitution seems to be triggered by the native segment inventory constraint (Madiba, 2010). In terms of this constraint foreign sounds which do not occur in the recipient language sound inventory are barred from occurring and are therefore substituted by native ones.

\subsection{Substitution of Consonants}

Words borrowed from other languages are treated according to the sound system of the receiving language. Loanwords whose phonological structure does not fit into the phonology of the borrowing language need to be adapted to fit that phonological system, and consistent patterns of adaptation can be explained by assuming particular rankings of phonological constraints (Prince and Smolensky 1993).

When producing a loanword, speakers attempt the closest proximation to the model. However, because the SL and RL phonological patterns do not correspond identically, speakers may have to exercise sound alternation because the RL does not have the sounds that are in the SL (Hafez, 1996). To facilitate their production, speakers of Bemba resort to the closest native sound available in their repertoire.

In an attempt to facilitate our analysis of loanword adaptation in Bemba, it is important to look at both English and Bemba phonological systems.

Table1. English Consonants

\begin{tabular}{|c|c|c|c|c|c|c|c|c|}
\hline & Bilabial & Labiodental & Dental & Alveolar & Palato alveolar & Palatal & Velar & Glottal \\
\hline Plosive & $\mathrm{p} \mathrm{b}$ & & & $\mathrm{t} d \mathrm{~d}$ & & & $\mathrm{~kg}$ & \\
\hline Fricative & & $\begin{array}{ll}\mathrm{f} & \mathrm{v} \\
\end{array}$ & $\begin{array}{ll}\theta \theta & \text { ठ } \\
\end{array}$ & $\begin{array}{ll} & Z \\
\end{array}$ & $\int 3$ & & & $\mathrm{~h}$ \\
\hline Affricate & & & & & $\mathrm{t} \int \mathrm{d} 3$ & & & \\
\hline Nasal & $\mathrm{m}$ & & & $\mathrm{n}$ & & & $\eta$ & \\
\hline Lateral & & & & 1 & & & & \\
\hline Approximant & $\mathrm{W}$ & & & & $\mathrm{r}$ & $\mathrm{J}$ & & \\
\hline
\end{tabular}

Source: (Roach, 1983 p. 52) 
Table2. Bemba Consonants

\begin{tabular}{|l|l|}
\hline Stops & $\mathrm{p}, \mathrm{t}, \mathrm{k}$ \\
\hline Fricatives & $\mathrm{b}, \mathrm{f}, \int$ \\
\hline Affricates & $\mathrm{t} \int$ \\
\hline Nasals & $\mathrm{n}, \mathrm{m}, \mathrm{n} \quad \mathrm{g}$ \\
\hline Liquids & $\mathrm{L}$ \\
\hline Glides & $\mathrm{y}, \mathrm{w}$ \\
\hline
\end{tabular}

Adapted from: (Kula, 2002 p.48)

As can be seen from the two tables above, Bemba lacks some phonemes found in English. These facts are key concerns when an English word is borrowed into Bemba. Logically, these missing sounds are substituted by the closest sounds that exist in Bemba.

According to Hussain et al, (2011), substitution is a general tendency to preserve sounds from deletion and it tries to reshape the word closer to the input form, but at the same time because some sound combinations are not allowed in the recipient language, they undergo certain adaptations. In substitution, an item is replaced to the phonetically-close phonemes in the recipient language (Hock, 1991).

Substitution is a process that takes place during borrowing and involves substituting consonants in the source language with others in the receiving language. It is usually attributed to the absence of equivalents in the receiving language. Absent segments will always be assigned the closest bundle in L1 (Antila, 1972). This therefore implies that if a segment is absent in Bemba, then a bundle that is close to it in Bemba will be used to substitute it. Sometimes a sound segment from English may be perceived differently by the Bemba people leading to substitution.

Since source and receiving languages most often do not have the same inventory of sounds, one obvious way in which loanwords are modified is by sound substitutions. That is, for any source language sound which the receiving language lacks, the phonetically closest sound is substituted.

In this case, English consonants which are not found in the Bemba consonantal inventory are substituted by those that are found in Bemba. English sounds which are not found in Bemba are substituted by the Bemba sounds that are phonetically close to them. This observation is illustrated in the following examples:

\subsubsection{Devoicing}

According to Collins English Dictionary (2015), in phonetics, devoicing is the process by which a consonant that is usually voiced becomes devoiced. It was discovered that devoicing phonemes was common in the process of adaptation of lexical borrowings from English to the Bemba phonological system. It should however be mentioned that Town Bemba maintains the existence of the voiced phonemes in English loanwords.

- d-devoicing: This rule states that English /d/ which is not preceded by a nasal is realised as / $\mathrm{t}$ / (its voiceless counterpart) in Bemba:

$$
\mathrm{d} \rightarrow \mathrm{t}
$$

$\begin{array}{lc}\text { English } & \text { Bemba } \\ \text { Adam } & \text { [Ataamu] } \\ \text { damage } & \text { [taameci] } \\ \text { dance } & \text { [taansi] } \\ \text { deacon } & {[\underline{\text { tiikoni }]}} \\ \text { dear } & {[\text { tiiiya] }} \\ \text { DC } & \text { [tiishi] } \\ \text { desk } & \text { [teshiki] } \\ \text { dam } & \text { [tamu }\end{array}$

Note that there are a few exceptions where /d/ is preceded by a nasal: 
(2)

$\begin{array}{ll}\text { English } & \text { Bemba } \\ \text { doctor } & \text { [ndokotala] } \\ \text { Diana } & \text { [Ndaina] }\end{array}$

- g-devoicing: This rule states that English $/ \mathrm{g} /$ is realised as $/ \mathrm{k} /$ (its voiceless counterpart) in Bemba:

$$
\mathrm{g} \rightarrow \mathrm{k}
$$

(3)

$\begin{array}{lc}\text { English } & \text { Bemba } \\ \text { garage } & {[\text { kaalaci] }} \\ \text { garden } & \text { [ } \text { kaalateni] } \\ \text { garlic } & {[\text { kaaliki] }} \\ \text { gate } & {[\underline{\text { keeti }]}} \\ \text { gear } & {[\text { kiiiya] }} \\ \text { gift } & {[\text { kiifuti] }} \\ \text { bag } & {[\text { baaki }]} \\ \text { gold } & {[\text { kolite] }}\end{array}$

- $\mathbf{v}$ - devoicing: This rule states that English / $\mathrm{v} /$ is realised as /f/ (its voiceless counterpart) in Bemba:

$$
\mathrm{v} \rightarrow \mathrm{f}
$$

(4)

English

valve

vest

vaseline

varnish

vote

five

November
Bemba

[faalufu]

[feshiti]

[fashilini]

[fanishi]

[foota]

[faifi]

[Nofemba]

- dz- devoicing: This rule states that English /dz/ is realised as /c/ (its voiceless counterpart) :

$$
\mathrm{d}_{3} \rightarrow \mathrm{c}
$$

(5)

English

charger / $/ \mathrm{t} \int \mathrm{a}: \mathrm{d} z \partial(\mathrm{r}) /$

judge $/ \mathrm{d} z \Lambda \mathrm{d} z /$

jackpot /'dzækppt/

George /dzodz/

join /dzom/

jar /dza:(r)

July /dzu`lai/

Junior /'dzu:niə(r)
Bemba

[caaca]

[caaci]

[cakipoti]

[Cooci]

[coini]

[caa]

[Culai]

[Cuunya]

- $/ \theta /$ and /ð/ devoicing: This rule states that English $/ \theta /$ and $/ \delta /$ are realised as either $/ \mathrm{t} / \mathrm{f} / \mathrm{f} / \mathrm{or} / \mathrm{s} / \mathrm{in}$ Bemba: 
(6)

$$
\theta / \square \rightarrow\left(\begin{array}{l}
\mathrm{f} \\
\mathrm{s}
\end{array}\right)
$$

\begin{tabular}{|c|c|}
\hline \multicolumn{2}{|l|}{ English } \\
\hline father/`fa:ðə & [fáása] \\
\hline bathroom / ba:Өru:m/ & [baafwa] \\
\hline Arthur /'a: $\theta \mathrm{a} /$ & [aasa] \\
\hline theatre $/{ }^{\prime} \theta \operatorname{s} \partial t \partial(\mathrm{r}) /$ & [fyééta] \\
\hline catholic / kæolik/ & [kaatolika] \\
\hline Corinthian /ka'rin $\theta \mathrm{an} /$ & [koliinto] \\
\hline Goliath /ga'laia日/ & [Kolyaati] \\
\hline three /'Ori:/ & [fili] \\
\hline
\end{tabular}

- $\mathbf{z}$ - devoicing: This rule states that English /z/ is realiesd as /s/ (its voiceless counterpart) in Bemba:

$$
\mathrm{z} \rightarrow \mathrm{s}
$$

\begin{tabular}{|c|c|}
\hline English & Bemba \\
\hline zero & [shiilo] \\
\hline zone & [ㅇooni] \\
\hline zip & [shiipu] \\
\hline size & [saishi] \\
\hline dozen & [taseni] \\
\hline
\end{tabular}

(7)

1.1.2. $s+i / c$ insertion: This rule states that English $/ \mathrm{s} /$ followed by $/ \mathrm{i} /$ or any other consonant is realised as /sh/ in Bemba:

$$
\mathrm{s}+\mathrm{i} / \mathrm{c} \rightarrow \mathrm{sh}
$$

(8)

$\begin{array}{lc}\text { English } & \text { Bemba } \\ \text { scone } & \text { [ishikoono[ } \\ \text { spanner } & \text { [shipaana] } \\ \text { spare } & \text { [shipeeya] } \\ \text { basket } & {[\text { bashikeeti[ }} \\ \text { steak } & \text { [shiteeki] } \\ \text { pastor } & \text { [pashita] } \\ \text { sink } & \text { [shiinki] }\end{array}$

1.1.3. $r$-lateralisation: This rule states that English $/ \mathrm{r} /$ is realised as $/ 1 / \mathrm{in}$ Bemba:

$$
\mathrm{r} \rightarrow 1
$$

(9)

$\begin{array}{ll}\text { English } & \text { Bemba } \\ \text { radio } & \text { [leetiyo] } \\ \text { rape } & \text { [leepu] } \\ \text { rake } & \text { [leeki] }\end{array}$




$\begin{array}{ll}\text { lorry } & {[\text { loole }]} \\ \text { room } & {[\text { luumu }} \\ \text { ruler } & {[\text { luula }]}\end{array}$

1.1.4. $b$-fricatisation: This rule states that English plosive $/ \mathrm{b} /$ is realised as fricative $/ \beta /$ in Bemba except before a nasal compound.

$$
\mathrm{b} \rightarrow \beta
$$

$\begin{array}{ll}\text { English } & \text { Bemba } \\ \text { bag } & {[\not \beta a a k i]} \\ \text { ball } & {[\not \beta o o l a]} \\ \text { band } & {[\underline{\text { aaandi }]}} \\ \underline{\mathrm{b}} \mathrm{ar} & {[\underline{\mathrm{a} a \mathrm{a}}]} \\ \mathrm{club} & {[\mathrm{akalaa} \beta \mathrm{u}]} \\ \text { hub } & {[\mathrm{aa} \beta \mathrm{u}]}\end{array}$

The above information can be summarised as follows:

\begin{tabular}{|l|}
\hline Rules \\
\hline $\mathrm{d} \rightarrow \mathrm{t}$ \\
\hline $\mathrm{g} \rightarrow \mathrm{k}$ \\
\hline $\mathrm{z} \rightarrow \mathrm{s}$ \\
\hline $\mathrm{v} \rightarrow \mathrm{f}$ \\
\hline $\mathrm{r} \rightarrow \mathrm{l}$ \\
\hline $\mathrm{s} \rightarrow \mathrm{sh}$ \\
\hline $\mathrm{b} \rightarrow \beta$ \\
\hline$\theta$ and $\mathrm{d} \rightarrow \mathrm{t}, \mathrm{f}, \mathrm{s}$ \\
\hline $\mathrm{d} 3 \rightarrow \mathrm{c}$ \\
\hline
\end{tabular}

Table2. Substitution of consonants

\subsection{Consonant Preservation}

It should however be noted that not all consonants are substituted when English words are borrowed into Bemba. The following are some consonants that are preserved in Bemba as loanwords from English enter it:

$\begin{array}{lll}\text { English } & \text { Bemba } & \text { Consonant preserved } \\ \text { /paen/ pan } & \text { /pani/ } & / \mathrm{p} / \\ \text { /kaendl/ candle } & / \text { kandulo/ } & / \mathrm{k} / \\ \text { /ti:m/ team } & / \mathrm{timu} / & / \mathrm{t} /\end{array}$

The above loanwords show the consonants that are preserved in English loanwords in Bemba.

\subsection{Conclusion}

In the above discussion, consonant substitutions in English loanwords in Bemba have been discussed. The discussion was based mainly on the substitution of English consonants which do not have equivalents in Bemba. These sounds are restrained from occurring in the Bemba language by the native segment inventory constraint Therefore they are replaced by sounds which are phonetically closest to them.

\section{REFERENCES}

[1] Anttila, R. (1972). An Introduction to Historical \& Comparative Linguistics. London: Macmillan Publishers.

[2] Hafez, Ola. (1996). Phonological and Morphological Integration of Loanwords into Egyptian Arabic. Les langues en Égypte.

[3] https://www.collinsdictionary.com/dictionary/english

[4] Hock, H. H. (1991). Principles of Historical Linguistics. New York: Mounton de Gruyter 
[5] Hussain Q. et, al (2011). Vowel Substitution: A Comparative Study of English Loans in Punjabi and Urdu. International Journal of Linguistics, Vol. 3, No. 1: E31

[6] Prince, A and Paul S. (1993). Optimality Theory: Constraint Ranking in Generative Grammar. Tech. Rep. \#2 of the Rutgers Center for Cognitive Sciences, Rutgers, NJ.

[7] Swann, J., Duemert, A., Lillis, T., \& Mesthrie, R. (2004). A Dictionary of Sociolinguistics. Alabama: The University of Alabama Press.

Citation: Kangwa Njenje, Kennedy. "The Adaptation of Consonants From English Loanwords into Bemba." International Journal on Studies in English Language and Literature (IJSELL), vol 5, no. 9, 2017, pp. 21-26. doi:http://dx.doi.org/10.20431/2347-3134.0509003.

Copyright: (C) 2017 Authors. This is an open-access article distributed under the terms of the Creative Commons Attribution License, which permits unrestricted use, distribution, and reproduction in any medium, provided the original author and source are credited. 